\title{
Pohjoisen muuttuva ympäristö
}

Markku Lehtimäki \& Arja Rosenholm 
uomen Akatemian rahoittama konsortio Pohjoisen muuttuva S ympäristö: Kulttuuriset representaatiot ja veden käyttötavat (The Changing Environment of the North: Cultural Representations and Uses of Water [CEN], 2017-2021) on monitieteinen hanke, jossa tutkitaan pohjoisen ympäristön ja arktisten alueiden inhimillisiä ja kulttuurisia merkityksiä. Projektin keskeisenä kysymyksenä on, miltä pohjoinen ja arktinen näyttävät, kun kartoitamme sen historiaa, maantiedettä, kieliä ja kertomuksia pikemminkin veden kuin maan kautta.

Pohjoinen on tyypillisesti nähty perifeerisenä ja mystisenä Toisena, jota vasten on voitu heijastaa omia toiveita, pelkoja ja unelmia. Erityisesti arktinen on kuvissa ja mielikuvissa kimmeltävä valon ja pimeyden, lumen ja jään valtakunta, joka esitetään konventionaalisesti ikuisesti samanlaisena. Projektimme kuitenkin korostaa, että myös vedellä - kuten Jäämerellä - on historiansa. Tutkimushankkeemme etsiikin mahdollisuuksia kulttuuri- ja ympäristöhistorian kirjoittamiseen akvaattisen maailman näkökulmasta. Tutkijoiden yhteinen näkökulma, joka korostaa pohjoisten vesien sosiaalista ja historiallista kontekstia, haastaa maahan kytketyn historiankirjoituksen ja etsii vaihtoehtoisia karttoja maata ja vettä erottavalle modernin dualismille. Kysymys veden muutosvoimasta materiaalisena ja metaforisena toimijana korostuu erityisesti arktisilla alueilla.

Arktinen alue on muuttumassa ilmaston lämpiämisen ja luonnonvarojen hyödyntämisen seurauksena globaalien intressien uudeksi keskukseksi ja geopoliittisten keskustelujen kohteeksi. Pohjoisen ja arktisen voimakas näkyminen visuaalisessa mediassa - valtioiden lippujen kiinnittäminen Jäämeren pohjaan tai jääkarhujen elinolot hupenevilla jäälautoilla - rakentaa omaa retorista viestiään, jonka tarkempi kirjallisuustieteellinen ja kulttuurintutkimuksellinen analyysi on olennaista. Keskustelua pohjoisesta ja arktisesta ei pidä jättää yksinomaan talouden, tekniikan ja politiikan diskursseille. Tästä syystä projektimme tarkastelee sekä inhimillisiä kokemuksia että luonnollista ympäristöä osana arktista todellisuutta, jota tutkitaan monitieteisen humanistisen tutkimuksen (kirjallisuudentutkimuksen, kielitieteen, historiantutkimuksen ja kulttuurimaantieteen) metodein. Tutkimus yhdistää erilaisia aineistoja (kaunokirjallisuutta, matkakertomuksia, karttoja, haastatteluja, valokuvia, elokuvia, kielidokumentaatiota) ja pyrkii tuottamaan uutta tietoa pohjoisen ja erityisesti arktisen alueen elämästä ja kertomuksista sekä niiden vaikutuksesta nykykeskusteluun.

Hanke tarkastelee pohjoisen ja arktisen alueiden historiaa, geopoliittista todellisuutta sekä taiteessa ja mediassa tuotettuja kuvia ja kuvitelmia veden ja sen eri manifestaatioiden (jää, lumi, tulvat) kautta. Muuttuvaa pohjoista ympäristöä tutkitaankin projektissa ennen kaikkea "vedentieteen" (akvagrafian), ei niinkään maantieteen, näkökulmasta. Vedentiede eli akvagrafia merkitsee myös "kirjoittamisen" - laajasti ymmärrettynä - analyysia (scriptura aquae). Tällöin huomio kiinnittyy siihen, millä tavalla pohjoista ja arktista sekä eri- 
tyisesti niiden vesiä on kuvattu ja edelleen kuvataan tekstin ja kuvan keinoin. Historiallinen käsitys pohjoisen ja arktisen representaation rakentumistavoista kytkeytyy projektissa sen näkemiseen ja tulkitsemiseen, mitä muutoksia noissa kuvaustavoissa on tapahtunut audiovisuaalisen ja digitaalisen median aikakaudella. Pohjoista ja arktista koskevat kulttuuriset käsitykset, kerronnalliset keinot, kognitiiviset kehykset sekä metaforat ja muut kuvat ovat olleet niin hallitsevia, että niiden retorinen kuvausvoima on säilynyt - usein ongelmallisesti - myös uudemmissa, 2000-luvun esityksissä ja puhetavoissa. Niinpä tietyt tilalliset metaforat koskien tyhjyyttä, reunaa, väylää tai rajaa rakentavat edelleen pohjoisen myyttiä.

Eräs mahdollinen näkökulma tämänkaltaisen kuvaston ja sen kulttuurisen kierrätyksen säilyvyyteen on purkaa analyyttisesti pohjoisen ja arktisen sukupuolitettua konstruointia. Erityisesti arktinen on "tyhjänä" ja "valkoisena" alueena ollut pitkään niin historiassa kuin mielikuvituksessa maskuliinisen toiminnan ja kolonisaation kohde. Pohjoista ja arktista tilaa onkin kartoitettu ja representoitu matkakertomuksissa, panoraamoissa, romaaneissa, valokuvissa, elokuvissa, dokumentaareissa, sarjakuvissa, turistiesitteissä ja mainoksissa, jotka ovat usein tuottaneet etäännytetyn ja ulkopuolisen kuvan pohjoisen ja arktisen todellisuudesta. Pohjoinen ja arktinen on tällöin tuotettu poliittisesti ja ideologisesti kuvina ja metaforina, jotka ovat osaltaan kehystäneet ne ajattomiksi kertomuksiksi. Siksi on tärkeää myös lukea näitä esityksiä ja käsityksiä vastaan, kuuntelemalla myös alkuperäiskansojen edustajien ääniä ja kokemuksia etnografisen kenttätyön, haastattelujen ja kielidokumentaation avulla. Kysymykseksi tulee tällöin esimerkiksi, mitä merkityksiä eri kielissä annetaan vedelle ja merelle, jotka ovat elinkeinon lähde. Myös ei-inhimillinen luonto ja ei-inhimilliset eläimet on otettava huomioon laajemman ja todemman kuvan hahmottamiseksi. Projektissamme onkin mukana kriittisen eläintutkimuksen, uusmaterialismin ja posthumanismin näkökulmia.

Yksi arktisen tutkimuksen keskeinen maan- ja vedentieteellinen painopiste on Venäjän pohjoisessa. Arktisen merkitys Venäjällä on kasvanut erityisesti viime aikoina geopoliittisten ja globaalin talouden intressien sekä identiteettipolitiikan diskursseissa. Samalla myös venäläinen kirjallisuuden- ja kulttuurintutkimus on osoittanut uudenlaista kiinnostusta Venäjän pohjoista kohtaan. Hankkeemme Venäjään kohdistuva osatutkimus tarkastelee kriittisesti kulttuurisemioottisia konsepteja (esimerkiksi "pohjoisen teksti", severnyj tekst), jotka näkevät pohjoisvenäläisyydessä myyttisen version venäläiskansallisesta maailmankuvasta sekä pohjoisen koko Venäjän synekdokeena. Samoin siinä tutkitaan populaarikulttuurin visuaalisia esityksiä Venäjän roolista arktisena suurvaltana. Hankkeessa valmistuu myös väitöskirja, joka tarkastelee Venäjän arktisen alueen alkuperäiskansojen kirjallisuutta ja siinä asukkaiden ja ei-inhimillisen luonnon suhdetta. Oman tutkimuskohteensa tarjoaa myös venäläinen kirjallisuus ja elokuva, joiden tapahtumat sijoittuvat Jäämeren rannoille. Meren ja maan väliselle liminaalivyöhykkeelle sijoittuvat tapahtumat kertovat tasa- 
painoilusta alkuperäiskulttuurin ja valtakulttuurin välillä, mutta merenrannan kronotooppi tarjoaa myös tuoreita tulkintamahdollisuuksia tapahtumien epistemologisista ja esteettisistä merkityksistä.

Konsortio on järjestänyt vuosittain kansainvälisiä symposiumeja ("Visual Perspectives on the North and the Arctic", "Water, Animals, and Arctic Climate Change", "Aquagraphy" ja "The Changing Environment of the North") ja sen puitteissa on valmistunut kolme artikkelikokoelmaa: Veteen kirjoitettu: Veden merkitykset kirjallisuudessa (SKS 2018), Visual Representations of the Arctic: Imagining Shimmering Worlds in Culture, Literature and Politics (Routledge 2021) ja Cold Waters: Flows of Knowledge and Means of Thinking (Springer Nature, tulossa). Konsortio on ollut sijoitettuna kestonsa aikana kolmessa yliopistossa, Itä-Suomen yliopistossa, Tampereen yliopistossa ja Turun yliopistossa. Sen vastuullisina johtajina ovat toimineet yleisen kirjallisuustieteen professori Markku Lehtimäki (Turun yliopisto) ja venäjän kielen ja kulttuurin professori Arja Rosenholm (Tampereen yliopisto). Hanke on ollut myös jatkoa Arja Rosenholmin johtamalle, Suomen Akatemian rahoittamalle tutkimusohjelmalle Vesi sosiaalisena ja kulttuurisena tilana (Water as Social and Cultural Space, 2012-2016). Rahoitettuina tutkijoina eri yliopistoissa ovat Pohjoisen muuttuva ympäristö -projektin aikana työskennelleet Elina Arminen, Eevastiina Kinnunen, Eeva Kuikka, Toni Lahtinen, Tatu Laukkanen, Lotta Luhtala, Natalia Mihailova, Maija Ojala-Fulwood, Michael Riessler, Anna Stammler-Gossmann, Vlad Strukov ja Elena Trubina.

Hankkeen kotisivut: https://sites.utu.fi/aqua-cen/en/ 